Chang, C. \& Hurst, B. \& McLean, A. (2015). You've Got Mail: Student Preferences of Instructor Communication in Online Courses in an Age of Advancing Technologies. Journal of Educational

Technology Development and Exchange, 8(1), 39-37.

\title{
You've Got Mail: Student Preferences of Instructor Communication in Online Courses in an Age of Advancing Technologies
}

\author{
Ching-Wen Chang \\ Missouri State University \\ Beth Hurst \\ Missouri State University \\ Annice McLean \\ Missouri State University
}

\begin{abstract}
The purpose of this study was to determine students' current preferred ways to receive course communication from their online instructors. In a time when technology is changing daily, and a time when young people are often the most up-to-date with that new technology, students' preferences for how they receive online course communication is apt to change often too. In order to determine students' current preferences, a survey was administered two semesters to both graduate and undergraduate students enrolled in an at least online course at a university in the Midwest. Survey results indicated that $97 \%$ of the students preferred to receive communication from their online instructors through email, and secondly, through course announcements posted in the learning management system. These findings provide valuable information for instructors who teach online courses to help them determine the most effective strategies for communicating with their students.
\end{abstract}

Keywords: Online Course Communication, Instructional Strategies, Communication through Learning Management Systems, Video Communication, Communication Strategies

\section{Introduction}

The primary goal of an instructor is to facilitate student learning (Anglin \& Morrison, 2002; Bulger, Mohr, \& Walls, 2002; Vacca, Vacca, \& Mraz 2014). Educators spend a significant amount of time developing different instructional strategies in the hope these strategies will enhance learning, improve outcomes, and make the learning process more relevant for students. Research has shown that active student engagement in the learning 
process enhances knowledge acquisition and retention (Vacca et al., 2014). The use of classroom strategies that encourage student involvement and interaction with the instructor can facilitate higher learning outcomes (Polloff \& Pratt, 2007; Todd \& Hudson, 2007; Vacca et al., 2014). How online instructors make all of these connections with students depends largely on their ability to communicate electronically in an age when students are technologically advanced. One of the most important components of online instruction is communication as a means to engage students in learning (Tubbs \& Mos, 2006).

In a time when technology is changing daily, and a time when young people are often the most up-to-date with that new technology, students' preferences for how they receive online course communication is apt to change often too. While prior research has shown that students preferred email as the method of communication from their online instructors (Frey, Faul, \& Yankelov, 2003; Woods, 2002), technology has continued to change, so it is important to determine if that is still the preferred method and to determine if there might be new technologies they now prefer more. Given the functionality of today's learning management systems, online instructors have a variety of communication strategies from which to choose. The purpose of this study was to determine students' current preferred ways to receive course communication from their online instructors. Before providing the survey results, what follows is a review of the relevant literature.

\section{Relevant Literature}

Teaching and learning are dynamic interactions constantly occurring between students and instructors and among students themselves. Studies have shown the importance of interaction in the online learning environment as well as being a key indicator of the effectiveness of a course (Berge, 1999; Flottemesch, 2000; Jiang, 1998; Jin, 2005; Polloff \& Pratt 2007; Su, Bonk, Magjuka, Liu, \& Lee 2005). Jiang (1998) found that students tend to demonstrate higher achievements in online courses that place an emphasis on interaction. Jin (2005) found that "web-based communication tools are effective means to help students construct their own knowledge through interactions" (p. 66). Polloff and Pratt (2007) stated that in an online environment, the "key to the learning process are the interactions among students themselves, the interactions between faculty and students, and the collaborations in learning that results from these interactions" (p. 4). Their findings suggest that when instructors promote frequent communication with their students and provide prompt feedback, students are more satisfied with the course.

Around the early 1970s, the primary platform of human communication started shifting to computer networks (Quarterman, 1993). Not long after, computer technology began making inroads into the educational field as a means to deliver knowledge (Molnar, 1997). Since that time, numerous digital communication technologies such as email, asynchronous discussion, instant messaging, online chat, and computer apps, among others, have been utilized to encourage interaction and communication in the online learning environment. McGreal (2004) indicated that the use of different technology tools, when properly implemented in instructional activities, enhance interactions.

Most professional educators have concerns about adequate communication when creating an online course, or transitioning a face-to-face course into a web-based course, and how to best communicate with their students. Even taking into consideration the various educational technologies available, the 
tool that is most often used to communicate in an online class is email. Waldeck, Kearney, and Plax (2001) stated "research on advanced instructional technologies has, for the most part, neglected what is perhaps the most frequently used form of mediated communication among teachers and studentselectronic mail (e-mail)" (p. 55). In one study, Frey et al. (2003) found that “...students perceive email communication with the instructor and the online provision of course information as the most valuable strategies" (p. 443). In fact, they found it difficult to even find an instructor who does not use email to communicate with students. Woods (2002) reported in his research that students appreciated both academic and non-academic email responses from their instructor. And further stated that "some students, regardless of frequency levels, were positively affected by and benefited from receiving instructorinitiated personal emails outside of required group discussion formats" (p. 389). Anecdotally, these researchers also have found through comments from their students, that email communication, particularly feedback and non-academic advice, often provides students with more of a sense of community in an online learning environment.

From their inception, online courses were promoted as a way for students to learn anytime from anywhere. Today, distance education students have come to expect this flexibility in their course schedules. Email has become a convenient and flexible communication tool among teachers and students that does not require real time dialogue because email communication occurs asynchronously (Spears \& Lea 1994; Sproull \& Kiesler 1991). Unlike synchronous, real time communication tools such as online chat, videoconferencing, or instant messaging, email does not require students to be available as communication takes place. Frey et al. (2003) stated that "Although at least $75 \%$ of students were exposed to all available communication strategies, only the perceived value of email communication with the instructor ranked high compared to the other strategies" (p. 449).

\section{Purpose of the Study}

The purpose of this study was to determine students' current preferred ways to receive course communication from their online instructors. With quickly changing technology, students' preferred ways of receiving course communication might change quickly as well, so online instructors will benefit from knowing students' current preferences.

\section{Method and Participants}

This study utilized a survey design, a preexperimental, descriptive research method that accommodated the intent of this study well. In survey designs, the "focus is directed more toward learning about a population and less on relating variables" (Creswell, 2005, p. 354). The survey design "...consists of two elements-a single instance of a causal event and the assessment of its effects" (Cherulnik, 1983, p. 158).

This study utilized a sample of convenience consisting of undergraduate and graduate education students at a university in the Midwest with approximately 25,000 students. The majority of participants at the undergraduate level were pre-service teachers from early childhood, elementary, middle school, special education, as well as some secondary education majors. The participants at the graduate level were from literacy, educational technology, elementary and secondary education. The voluntary return response rate was 45\% (213 surveys returned out of 470 sent). Table 1 shows 
the demographic data obtained for students' gender, age, level in school, and the number of online courses they have taken. the age of $30: 76 \%$ of the undergraduates were ages $18-22$, and $46 \%$ of the graduates were ages 23-30. Close to half of the students

Table 1. Demographic summary

\begin{tabular}{|c|c|c|c|}
\hline & & $n$ & $\%$ \\
\hline \multicolumn{4}{|l|}{ gender } \\
\hline & Female & 174 & 82 \\
\hline & Male & 39 & 18 \\
\hline \multicolumn{4}{|l|}{ Age } \\
\hline & $18-22$ & 83 & 39 \\
\hline & $23-30$ & 72 & 33 \\
\hline & $31-40$ & 36 & 17 \\
\hline & $41-59$ & 22 & 10 \\
\hline & Over 60 & 1 & .5 \\
\hline & Would rather not report & 1 & .5 \\
\hline \multicolumn{4}{|c|}{ level in school } \\
\hline & Undergraduate & 103 & 48 \\
\hline & Graduate & 102 & 48 \\
\hline & Non-degree seeking & 9 & 4 \\
\hline \multicolumn{4}{|c|}{$\begin{array}{l}\text { Number of online } \\
\text { courses taken }\end{array}$} \\
\hline & 1 & 21 & 10 \\
\hline & 2 & 39 & 18 \\
\hline & 3 & 38 & 18 \\
\hline & 4 & 20 & 9 \\
\hline & More than 4 & 95 & 45 \\
\hline
\end{tabular}

$\mathrm{n}=213$ respondents

Gender response was predominately female with $174(82 \%)$ responding and $39(18 \%)$ male responses. The number of undergraduates and graduates who responded was almost equal with 103 undergraduates (48\%) and 102 graduates (48\%). Seventytwo percent of the respondents were under who responded to the survey, 95 (45\%), have taken more than four online classes. Graduate students have taken more online courses than undergraduates with $58 \%$ who have taken more than four, while $32 \%$ of the undergraduates have taken more than four. 


\section{Procedures and Data Collection}

In order to determine students' current preferred way of receiving course communication from their online instructors, an electronic online survey was distributed two semesters as a link in an email to 470 students who were enrolled in at least one undergraduate or graduate online course at the university. Participants were informed that the survey, which took less than five minutes to complete, was anonymous, voluntary, and that they were providing their consent by completing the survey. The data collected was used in aggregate so individual participants could not be identified.

In addition to demographic information that included students' gender, age, level in school, and the number of online courses they have taken, the only other question on the survey was the following: "What do you find is the best way for your instructors to contact you with course communication (announcements, reminders, etc.)?" Students were provided with a list of the following nine choices to rate on a Likert scale of strongly agree, agree, neutral, disagree, and strongly disagree: email, course announcements, audio announcements, video links of instructor talking, post on the discussion board, class blog posts, group texts, tweets, and online chatting via videoconferencing application (Skype, for example). Students were asked to rank the perceived value of each of the nine choices and to write in additional choices not listed.

\section{Results}

As shown in Table 2, of the 213 online students who responded to the survey, when asked their opinion of the best way for online instructors to contact them with course communication, email was the choice for the overwhelming majority (97\%) who reported strongly agree $(\mathrm{n}=179)$ or agree $(n=28)$. Posting in the announcements section

Table 1. Online students' preferred method of communication from instructors

\begin{tabular}{lccccc}
\hline & $\boldsymbol{S A}$ & $\boldsymbol{A}$ & $\boldsymbol{N}$ & $\boldsymbol{D}$ & $\boldsymbol{S D}$ \\
Email & 179 & 28 & 5 & 1 & 0 \\
Course announcements & 86 & 77 & 26 & 17 & 3 \\
Audio announcements & 16 & 28 & 88 & 45 & 29 \\
Video links of instructor talking & 44 & 56 & 55 & 34 & 19 \\
Post on the discussion board & 43 & 66 & 50 & 36 & 16 \\
Class blog posts & 25 & 46 & 77 & 44 & 17 \\
Group texts & 44 & 52 & 47 & 39 & 25 \\
Tweets & 6 & 6 & 45 & 65 & 84 \\
Online chatting via videoconferencing & 16 & 27 & 71 & 54 & 42 \\
application & & & & & \\
\hline
\end{tabular}

$\mathrm{n}=213$ respondents 
within the course was the second highest percentage with $77 \%$ reporting they either strongly agreed $(n=86)$ or agreed $(n=77)$. Of the remaining seven choices listed, three choices were reported strongly agree or agree by approximately half of the students: posting on the discussion board (51\%), video links of the instructor talking (47\%), and group texts $(45 \%)$. On the strongly disagree and disagree end of the spectrum, three were negative (tweets $70 \%$; video conferencing $45 \%$; audio $35 \%)$. Class blogs were fairly evenly split between strongly agree or agree (33\%), neutral $(36 \%)$, and strongly disagree or disagree $(29 \%)$.

\section{Discussion and Conclusion}

There are several important findings that can be gleaned from this study. First, email was clearly the preferred method of communication reported by the students overall and also across different variables in terms of gender, age, level of study, and number of online course experiences. Of the respondents who have taken more than four online courses, 98\% strongly agreed or agreed that email is the best and most convenient way to receive communication from their online instructors. The opinions of these students who have a great deal of experience with different online options and communication styles match those of students who have taken fewer online courses. A feature in many learning management systems for course announcements is the ability for the instructor to post an announcement as well as immediately send that announcement as an email to all students enrolled in the course. Using this functionality to send announcements as an email accommodates the preference of the vast majority of students, as shown in the data of this study.

Second, the least popular form of communication reported was Twitter. There were slight differences among student preferences about Twitter when examining participants' ages. The age group of 18-22 showed a slightly higher interest in Twitter $(10 \%)$ than other age groups. People in this age group are most likely more accustomed to using technology frequently in their lives as compared to those over 30 . However, $73 \%$ of participants across age groups reported they strongly disagreed or disagreed with this method of communication. Possible factors for the low interest in Twitter are this tool is not commonly integrated into online classes and the limited number of characters often cannot fully convey the message.

Third, the researchers expected participants to offer additional suggestions for some other means of communication especially using emerging technologies. However, only three suggestions were offered other than those listed on the survey: one student suggested a face-to-face meeting for the first class, one student suggested the use of Line (a messaging app), and one student suggested Wiggio (a group website).

With today's dramatic proliferation of social media, one might reasonably have expected the trend, especially among Millennials and younger individuals to favor social media and texting as the preferred method of general communication. According to Taylor and Keeter (2010) in their report of a large study by the Pew Research Center, "millennials outpace older Americans in virtually all types of internet and cell use" (p. 25). The report showed that millennials "are more likely to have their own social networking profiles to connect to the internet wirelessly when away from home or work, and to post video of themselves online" ( $p$. 25).

Be that as it may, Mark Apple, owner and 
chief strategist at Forward Push Media (cited in Dille, 2015) stated "...no one is constantly on social networks, but most people check email every day, whatever their demographic profile: In my opinion, email is the original social media" ( ๆ 7). The education research, including this study, corroborates this, and affirms that email is by far, still the preferred method of communication of online learners today.

\section{Future Research}

As with all studies, additional or tangential research into this topic would be useful. An interesting study might be to determine if the institution type affects the results concerning email as the preferred method of communication with online instructors. Would results differ if the participants were at a community college, professional school, or public versus private institution?

Future research into this topic might also address issues such as email response times. While email's convenience makes it preferred by nearly all (97\% in this study) online students, an unintended consequence of the ubiquitous use of email is that students now seem to expect $24 / 7$ access to their instructors. Emails come from students at all hours of the day and night, and they expect answers quickly. How fast is fast enough? Future research into students' expectations, especially in regards to what they consider a timely response, would be interesting and valuable information for online instructors 


\section{References}

Anglin, G. J., \& Morrison, G. R. (2002). Evaluation and research in distance education: Implications for research. In C. Vrasidas, \& G. V. Glass (Eds.), Distance education and distributed learning (pp. 157-180). Greenwich, CT: Information Age Publishing.

Berge, Z. (1999). Interaction in post-secondary web-based learning. Educational Technology, 39(1), 5-11.

Bulger, S. M., Mohr, D. K., \& Walls, R. T. (2002). Stack the deck in favor of your students by using the four aces of effective teaching. Journal of Effective Teaching, 5(2). Retrieved from http://www.uncw. edu/cte/et/articles/bulger/

Cherulnik, P. D. (1983). Behavioral research: Assessing the validity of research findings in psychology. New York, NY: Harper \& Row.

Creswell, J. W. (2005). Educational research: Planning, conducting, and evaluating quantitative and qualitative research (2nd ed.). Upper Saddle River, NJ: Pearson Education.

Dille, S. (April 2015). To speak Millennial, use email. Retrieved from http:// marketingland.com/speak-millennial-useemail-124811

Flottemesch, K. (2000). Building effective interaction in distance education: A review of the literature. Educational Technology, 40(3), 46-51.

Frey, A., Faul, A., \& Yankelov, P. (2003). Student perceptions of web-assisted teaching strategies. Journal of Social Work Education, 39(3), 443-457.

Jiang, M. (1998). Distance learning in a Web-based environment: An analysis of factors influencing students' perceptions of online learning (Doctoral dissertation, State University of New York at Albany)
Dissertation Abstracts International, 59-11 A, 4044.

Jin, S. (2005). Analyzing student-student and student-instructor interaction through multiple communication tools in webbased learning. International Journal of Instructional Media, 32(1), 59-67.

McGreal, R. (2004). Technologies of online learning (E-learning). In T. Anderson, \& F. Elloumi (Eds.), Theory and practice of online learning (pp.115-135). Athabasca, Canada: Athabasca University.

Molnar, A. (1997). Computers in education: A brief history. THE Journal, 24(11), 63-68.

Polloff, R. M., \& Pratt, K, (2007). Building online learning communities: Effective strategies for the virtual classroom (2nd ed.). San Francisco, CA: Jossey-Bass.

Quarterman, J. S. (1993). The global matrix of minds. In L. M. Harasim (Ed.), Global networks: Computers and international communication (pp. 35-56). Cambridge, MA: MIT Press.

Spears, R., \& Lea, M. (1994). Panacea or panopticon? The hidden power in computer-mediated communication. Communication Research, 21, 427-459.

Sproull, L., \& Kiesler, S. (1991). Connections: New ways of working in the networked organization. Cambridge, MA: Massachusetts Institute of Technology.

Su, B., Bonk, C. J., Magjuka, R. J., Liu, X., \& Lee, S. H. (2005). The importance of interaction in web-based education: A program-level case study of online MBA courses. Journal of Interactive Online Learning, 4(1), 1-19.

Taylor, P., \& Keeter, S. (Eds.). (2010). Millennials: A portrait of generation next. Washington, DC: Pew Research Center.

Todd, V., \& Hudson, J.C. (2007). Using graded peer evaluation to improve students' writing skills, critical thinking ability, and comprehension of material in a principles of public relations course. Journal of 
College Teaching \& Learning 4(10), 3946.

Tubbs, S., \& Moss, S. (2006). Human communications: Principles and contexts. New York, NY: McGraw-Hill.

Vacca, R. T., Vacca, J. L., \& Mraz. (2014). Content area reading (11th ed.). New York, NY: Pearson.

Waldeck, J., Kearney, P., \& Plax, T. (2001). Teacher e-mail message strategies and students' willingness to communicate online. Journal of Applied Communication Research, 29(1), 54-70.

Woods, R (2002). How much communication is enough in online courses? Exploring the relationship between frequency of instructor-initiated personal email and learners' perception of and participation in online learning. International Journal of Instructional Media, 29(4), 377-394.

\section{Contact the Author}

Ching-Wen Chang

Associate Professor

Educational Technology Program Coordinator

Department of Reading, Foundations and Technology

Missouri State University

Email:CChang@MissouriState.edu

\section{Beth Hurst}

Missouri State University

Email:CChang@MissouriState.edu

\section{Annice McLean}

Missouri State University

Email:CChang@MissouriState.edu 